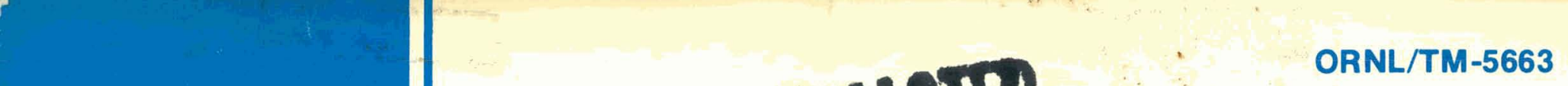

\title{
The Potential Use of Power Plant Reject Heat in Commercial Aquaculture
}

\author{
M. Olszewski
}

\section{OAK RIDGE NATIONAL LABORATORY}




\section{DISCLAIMER}

This report was prepared as an account of work sponsored by an agency of the United States Government. Neither the United States Government nor any agency Thereof, nor any of their employees, makes any warranty, express or implied, or assumes any legal liability or responsibility for the accuracy, completeness, or usefulness of any information, apparatus, product, or process disclosed, or represents that its use would not infringe privately owned rights. Reference herein to any specific commercial product, process, or service by trade name, trademark, manufacturer, or otherwise does not necessarily constitute or imply its endorsement, recommendation, or favoring by the United States Government or any agency thereof. The views and opinions of authors expressed herein do not necessarily state or reflect those of the United States Government or any agency thereof. 


\section{DISCLAIMER}

Portions of this document may be illegible in electronic image products. Images are produced from the best available original document. 


\section{Printed in the United States of America. Available from National Technical Information Service \\ U.S. Department of Commerce 5285 Port Royal Road, Springfield, Virginia 22161 \\ Price: Printed Copy $\$ 4.50$, Microfiche $\$ 3.00$}

This report was prepared as an account of work sponsored by the United States Government. Neither the United States nor the Energy Research and Development Administration/United States Nuclear Regulatory Commission, nor any of their employees, nor any of their contractors, subcontractors, or their employees, makes any warranty, express or implied, or assumes any legal liability or responsibility for the accuracy, completeness or usefulness of any information, apparatus, product or process disclosed, or represents that its use would not infringe privately owned rights. 
ORNL/TM-5663

Contract No. W-7405-eng-26

Engineering Technology Division

THE POTENTIAL USE OF POWER PLANT REJECT HEAT IN COMMERCIAL AQUACULTURE

M. O1szewsk1

Contributors

D. K. Cox

S. A.' Reed

J. S. Suffern

Date Published: January 1977

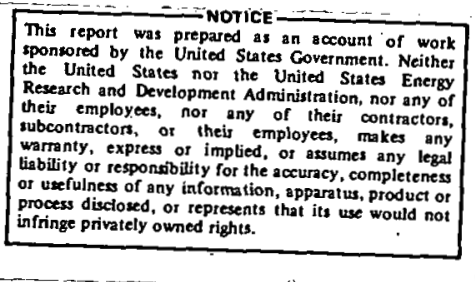

NOTICE: This document contains information of a preliminary nature. It is subject to revision or correction and therefore does not represent a final report.

\author{
Prepared by the \\ OAK RIDGE NATIONAL LABORATORY \\ Oak Ridge, Tennessee 37830 \\ operated by \\ UNION CARBIDE CORPORATION \\ for the \\ ENERGY RESEARCH AND DEVELOPMENT ADMINISTRATION
}




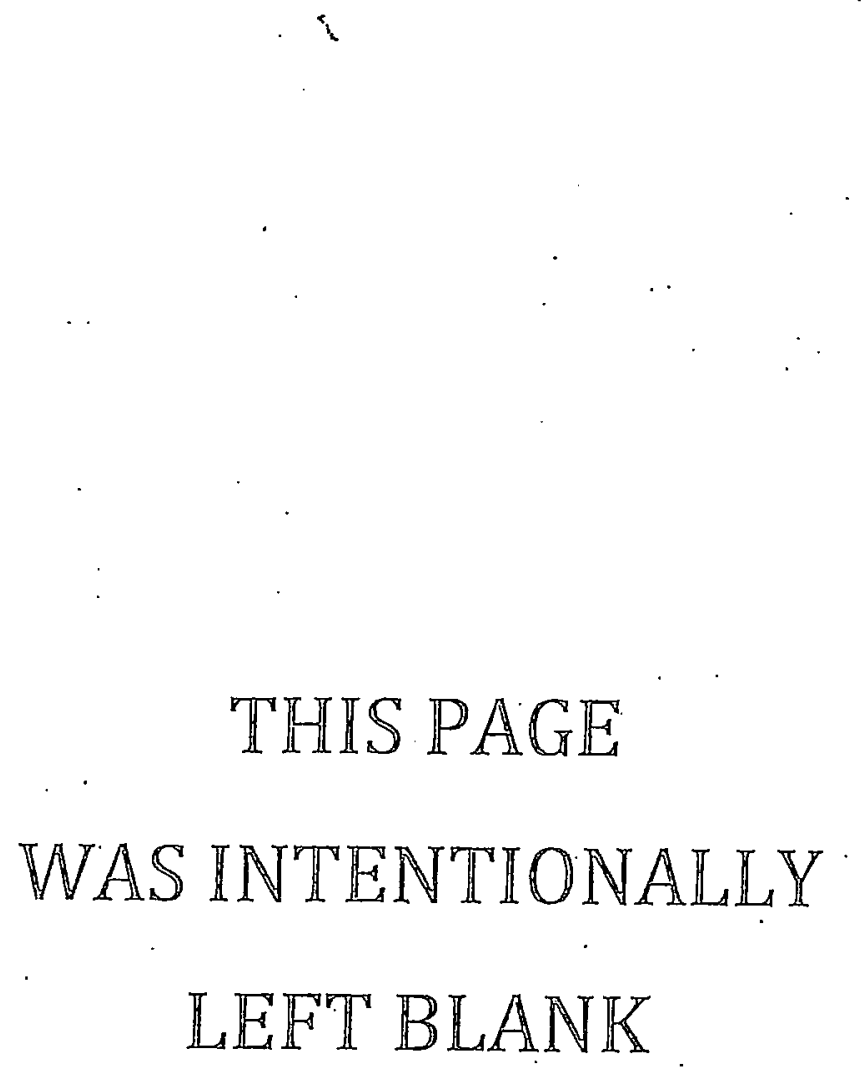


CONTENTS

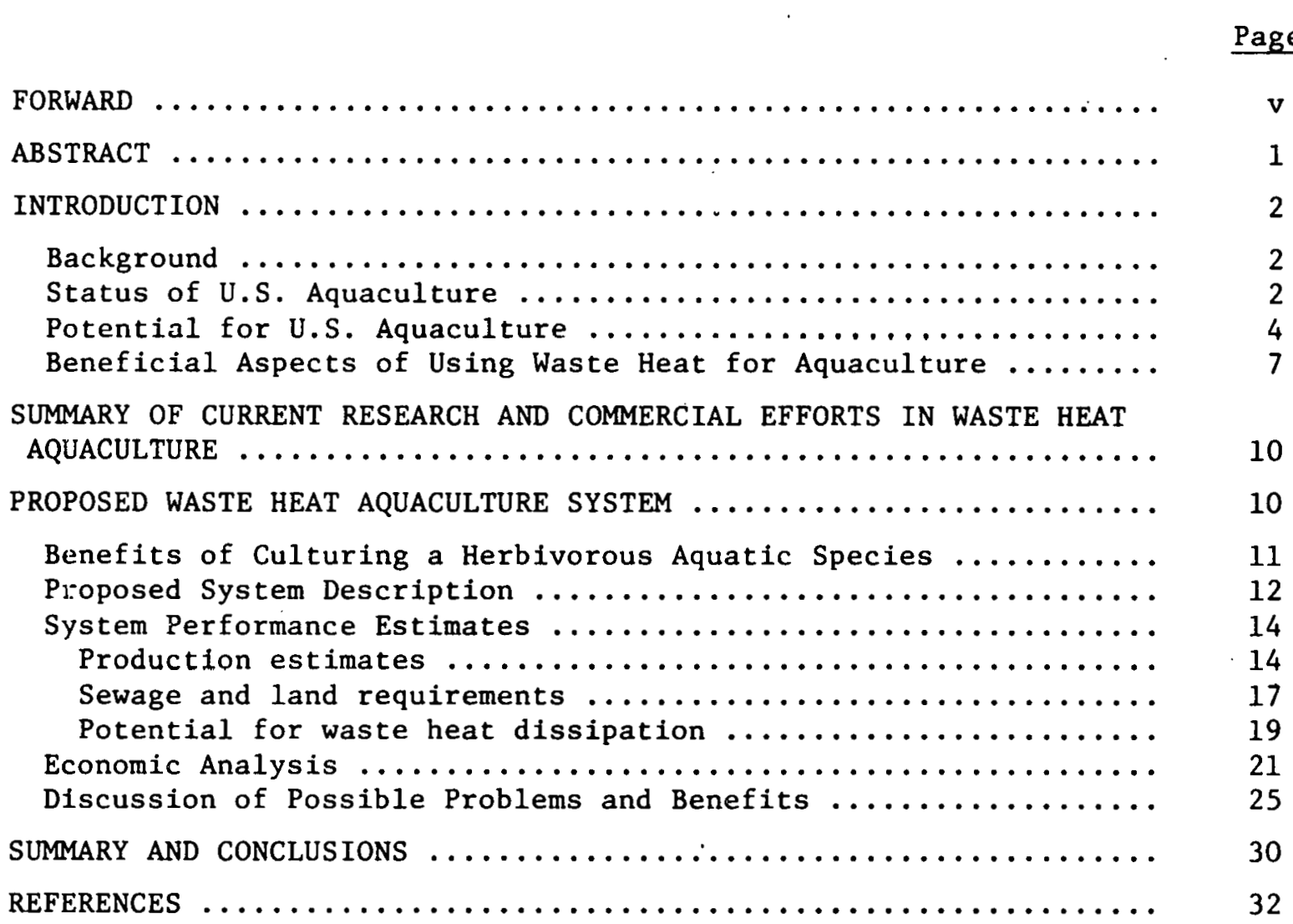

Appendix. TECHNICAL AND ECONOMIC ASSESSMENT OF CURRENT WASTE 
THIS PAGE

\section{WAS INTENTIONALLY LEFT BLANK}


FORWARD

It has been recognized that because of power cycle operating conditions nuclear power plants reject more waste heat per unit of electricity produced than comparable fossil stations. Because the waste heat problem is more severe for nuclear power stations, the Division of Nuclear Research and Applications, of the Energy Research and Development Administration, has sponsored research in the area of beneficial uses of waste heat for several years.

These investigations have considered various uses for power plant waste heat and have centered on agricultural uses. During the course of these investigations, it has become evident that utilization of waste heat in aquaculture systems has great potential. Therefore, this study was initiated to make a preliminary assessment of this application. 
THE POTENTIAL USE OF POWER PLANT REJECT HEAT IN COMMERCIAL AQUACULTURE

M. O1szewski

ABSTRACT

Current research and commercial activities in aquaculture operations have been reviewed. The potential market for aquaculture $f$ in and shellfish products has been examined, and it appears that a large potential market exists for moderately priced aquatic protein products. Consideration of the current activities and potential market has led to a new approach to waste heat aquaculture being proposed.

An aquaculture system using mostly herbivorous species in pond culture is proposed as a means of using waste heat to produce reasonably priced protein. The system uses waste water streams, such as secondary sewage effluent, animal wastes, or some industrial waste streams as a primary nutrient source to grow algae, which is fed to fish and clams. Crayfish feed on the clam wastes thereby providing a clean effluent from the aquaculture system. Alternate $\mathrm{fish}$ associations are presented and it appears that a carp or tilapia association is desirable. Analysis of the system indicates that a trade-off exists between the size of the aquaculture facility and the required cooling tower capacity. If the aquaculture facility is sized to operate at maximum production in winter, it is not capable of dissipating all the power plant waste heat in summer and cooling towers are required. If the aquaculture facility is sized to accommodate all of the reject heat in summer, protein production is reduced in winter because of insufficient heat available from the power plant.

An aquaculture system capable of rejecting all the wáste heat from a 1000-MW(e) power station in winter can accommodate about half the summer heat rejection luad. The aquaculture facility would require approximately 133 ha and would produce $4.1 \times 10^{5} \mathrm{~kg} /$ year of fish, $1.5 \times 10^{6} \mathrm{~kg} /$ year of $\mathrm{clam}$ meat, and $1.5 \times 10^{4} \mathrm{~kg} /$ year of live crayfish. The estimated annual pretax profit from this operation is one million dollars.

Several possible problem areas have been identifled. However, technical solutions appear to be readily available to solve these problems.

The proposed system shows considerable economic promise. Small scale experiments have demonstrated the technical feasibility of various components of the system. It therefore appears that a pilot scale experimental facility should be operated. 


\section{INTRODUCTION}

\section{Background}

The concept of aquaculture was first proposed nearly 2500 years ago when Fan Li, a Chinese scholar, wrote his treatise on the possibllity of ralsing fish in confinement. ${ }^{1}$ Since that time fish farming has been successfully practiced in small-scale applications. Anclent Japanese coastal inhabitants cordoned off small coves and estuarles to grow oysters and similar delicacies. Farmers have traditionally stocked farm punds wich local speccies, and mill owners long ago learned that their mill ponds could provide a regular supply of aquatic food and, sometimes, provide a surplus that could be sold.

Until recently a large percentage of fish farming was performed on a small subsistence scale. It required no advanced technology and 11ttle labor. Once the initial breeding stock was introduced, the fish survived in the natural ecosystem. The Japanese were first to improve these subsistence level operations. Space limitations and the high value of shellfish encouraged the Japanese to grow their oysters on multiple levels of small platforms suspended in the water. ${ }^{2}$ This began the trend to intensive (high technology) aquaculture methods that are typical of United States aquaculture efforts today. These methods seek to control temperature, dissolved oxygen content of the water, amount of food and other important growth parameters in an effort to maximize the productivity of a given volume of water. Intensive aquaculture, however, is expensive and this restricts the cultured species to varieties that command a premium price. Therefore, while many varteties of fin and shellfish are cultured throughout the world for their protein value, the U.S. aquaculture industry has concentrated on expensive delicacy varieties - shrimp, lobster, crab, oysters, salmon, trout, and catfish.

\section{Status of U.S. Aquaculture}

United States fish farms produced $59 \times 10^{6} \mathrm{~kg}\left(130 \times 10^{6} \mathrm{lb}\right)$ of fish in 1974. The major portion of this crop consisted of catfish and trout. Estimates from the National Marine Fisheries Service indicated little or 
no growth in U.S. fish farm production between 1973 and $1975 .^{2}$ However, the value of the U.S. aquaculture harvest is expected to rise to $\$ 374 \mathrm{mi1-}$ lion by $19822^{2}$

Most of the growth in commercial U.S. fish farming has been in catfish production. Production of farm-raised catfish has increased from $860,000 \mathrm{~kg}\left(1.9 \times 10^{6} \mathrm{lb}\right)$ in 1969 to $5.4 \times 10^{6} \mathrm{~kg}\left(11.8 \times 10^{6} \mathrm{lb}\right)$ in 1973 and is still rising. ${ }^{3}$ The industry began in the Mississippi delta region and has spread throughout the South and Into Oklahoma and Cal1fornia's Imperial Valley. Most of these growers recelved between $\$ 0.99-\$ 1.10$ per $\mathrm{kg}(\$ 0.45-\$ 0.50$ per $1 \mathrm{~b})$ for their stock in January $1976 .{ }^{3}$

United States commercial trout farming, in contrast, is concentrated almost exclusively in the 5178 ha (20 sq mile) Magic Valley in Southern Idaho. A cool climate and virtually limitless supply of cool mountain water have enticed trout farmers to this area. Although trout have been produced in the Magic Valley for generations, most of the trout farming industry development has occurred in the last 20 years. The largest portion of this growth occurred in the last 10 years, during which production increased by $100 \% .^{4}$

Six major producers and numerous farm pond growers in the Buhl-Twin Falls-Hagerman "magic circle" raise about $6.8 \times 10^{6} \mathrm{~kg}\left(15 \times 10^{6} \mathrm{lb}\right)$ of rainbow trout a year. Th1s represents about $90 \%$ of the processed production of this species in the U.S. 4

Other species that are commercially important include salmon, oysters, and s.1.ams. Salmon farming is, by comparison, an infant in the commercial aquaculture industry. It 1s, essentially, an emerging industry which is st111 in the research and development stage. The area of greatest activity is the Pacific Northwest, principally the Puget Sound area. There is also some activity in the Atlantic Northeast, especially in Maine.

Production of pan-sized salmon in the U.S. was about 350 metric tons during the 1973-74 growing season. 5 The bulk of this production came from Puget Sound netpens, primarily from one grower - Domsea Farms. In the 1974-75 growing season the total production of the U.S. Is expected to exceed 740 metric tons.

Oysters and clams are being commerclally produced on both coasts. The industry is relatively new, and utilizes power plant waste heat to 
accelerate growth in the hatchery. Since this industry is presently utilizing waste heat from power plants, it will be discussed in a later section of this report.

\section{Potential for U.S. Aquaculture}

In $1974,59 \times 10^{6} \mathrm{~kg}\left(130 \times 10^{6} \mathrm{lb}\right)$ or $5 \%$ of the total edible U.S. catch, came from fish raised on farms. ${ }^{1}$ This represented annual sales of $\$ 54$ milition. On the basis of a recent study, Frost aud sullivan, Inc., a New York based market research firm, projected that hy $1982 \mathrm{f}$ ish rainod in captivity will total $385 \times 10^{6} \mathrm{~kg}\left(848 \times 10^{6} \mathrm{lb}\right)$ or about $15 \%$ of the U.S. catch. Annual sales for these farmed fish could tota.1 $\$ 374$ million. The study concluded that aquaculture is now at a stage similar to the broiler chicken Industry 25 years ago, when that industry began to emerge from production on country farms to commerclal chicken factories.

In recent years, the U.S. has become increasingly dependent on imported fish to meet rising domestic demand. This indicates that the potential market for domestic aquaculture products is growing. The per capita consumption of seafood in the U.S. reached its high of $5.8 \mathrm{~kg}$

(12.7 1b) in 1973 and dipped slightly to $5.4 \mathrm{~kg}$ (12 1b) in 1974. However, the general trend is upward from the $4.8 \mathrm{~kg}(10.5 \mathrm{lb})$ in 1964 and $5.1 \mathrm{~kg}$ (11.2 1b) in 1969.

While the U.S. demand for fish has been rising, the proportion caught by U.S. fishing vessels has been declining. In 1964, U.S. fishermen caught $51 \%$ of the fish consumed in the U.S. By 1969, this percentage dropped to $41 \%$. In 1975 , U.S. fishermen caught only $37 \%$ of the 3.0 billion $\mathrm{kg}$ ( 6.6 billion $1 \mathrm{~b}$ ) of fish consumed in the U.S.

Replacing imported fish with domestic fish raised on fish farms presents a large and varled market for fish products. This market not only includes familiar aquatic species (salmon, trout, shrimp, etc.) but has the potential to utflize fish cultured throughout the world, but not commonly found in U.S. markets. Imports of frozen block fillet (cod, pollock, haddock, etc.) have been rising and totaled about 166 million $\mathrm{kg}$ (356 million 1b) in 1973. These frozen blocks are used by seafood manufacturers to produce fish sticks and portions. A recent study ${ }^{6}$ indicated 
that people who market block fish believe certain fresh water animals, among them tilapia, carp, and catfish, could substitute for these imports. Since frozen block $\mathrm{f}$ ish are now selling for $\$ 1.21-\$ 1.76$ per $\mathrm{kg}(\$ 0.55-$ $\$ 0.80$ per $1 \mathrm{~b})$, the sales potential in this market is upwards of $\$ 285 \mathrm{mil}-$ lion annually and presents an excellent potentlal market for species such as tilapia and carp.

If U.S. fish farms were to replace imports in the block fish market alone, the industry would have to triple its current production. Replacing $50 \%$ of the current 1mported fish with aquaculture products would mean increasing production to $945 \times 10^{6} \mathrm{~kg}\left(2.1 \times 10^{9} \mathrm{lb}\right)$, which represents about a fifteenfold increase over current production levels. Therefore, it is clear that a large potential market for aquaculture products exists in the U.S. that would not compete with the U.S. fishing industry.

Market trends also indicate that shellfish products grown in aquaculture facilities show a promising potential market. The total consumption of shellfish meat in the U.S. reached $241 \times 10^{6} \mathrm{~kg}\left(53.2 \times 10^{6} \mathrm{lb}\right)$ in 1975. Just over half of this total was accounted for by shrimp consumption. Other major items in this total included oysters, at $19.3 \times 10^{6} \mathrm{~kg}\left(42.6 \times 10^{6} \mathrm{lb}\right)$, and crabs and clams, both of which accounted for $28.9 \times 10^{6} \mathrm{~kg}\left(63.8 \times 10^{6} \mathrm{lb}\right)$. Comparative figures for 1971 show a total shellfish consumption of $224 \times 10^{6} \mathrm{~kg}\left(493 \times 10^{6} \mathrm{lb}\right)$, with shrimp again accounting for over half the total consumption. Crabs and clams accounted for about $8 \%$ of the total, or fust over $18.6 \times 10^{6} \mathrm{~kg}$ $\left(41 \times 10^{6} \mathrm{1b}\right)$. These figures Indicate that, although the U.S. total shellfish consumption grew only 8\% from 1971 to 1975, the market for clams grew by $56 \%$ in that time period. This upward trend in clam consumption is expected to continue unabated. Estimates from the National Marine Fisheries Service indicate that clam consumption is expected to continue rising and reach $43.5 \times 10^{6} \mathrm{~kg}\left(96 \times 10^{6} \mathrm{lb}\right)$ in 1982.

In the past, the shellfish fisheries have been able to increase production to meet the rising demand for their product. However, the oceans and rivers can only sustain a fishery of a given size. Taking into account current market trends, it is estimated that the maximum sustainable yield of clams from the world's seas will be reached by the 
year 2000. The impending scarcity of this product is, therefore, dictating that new sources be found to meet the rising demand.

At the present time, a bit over $98 \%$ of the clams marketed in the U.S. are wild clàms harvested from local waters. About $1 \%$ is imported, and the remainder ts supplied by clams raised on clam farms. Production estimates indicate that approximately $0.18 \times 10^{6} \mathrm{~kg}\left(0.4 \times 10^{6} \mathrm{Ib}\right)$ of farm raised clams were marketed domestically in 1973. Based on the increasing demand for clams and their declining natural avallability, projections indicate that clam farm production will be called upon to meet over $50 \%$ of the projected demand increase. This will result in farm-raised clam production rising to about $4.2 \times 10^{6} \mathrm{~kg}\left(9.2 \times 10^{6} \mathrm{lb}\right)$ in 1982. This represents a nearly 25-fold increase over current clam farm production.

Experfence in the oyster industry indicates that production on the scale outlined above is technologically feastble and can benefit from the use of heated water. In fact, raising shellfish in an artificially heated environment is a method commonly employed in the oyster hatchery industry. In this application, oyster seedlings are raised in heated water to accelerate growth. ${ }^{7}$ When they are comparable in size to a normal one-year-old oyster (usually in about two months) they are transferred to oyster beds in their normal growing environment. At the present time, about half of the oyster spat are started in controlled environments. Clams have also been shown to exhibit enhanced growth and survival when started in a controlled environment.

From the above discussion, it. is evident that rioing dcmand and declining natural supplies w111 result in an expanding market for farmraised clams. It is also evident that rearing clams in a controlled eñvironment using heated water presents several significant advantages. Since the commercial clam farm industry is in its infancy, most of the projected production increase in farm-raised clams will be from new facilities. Therefore, it is clear that a large potential market for clam aquaculture products exists in the U.S. that would not compete with the existing U.S. clam fisheries.

The projected markets for clam and finfish aquaculture products, therefore, -seek to satisfy an expanding demand rather than displace 
domestic products now on the market. Thus implementation of aquaculture for these species would probably not compete with established small sized domestic fish farms (whose major production is centered in catfish and trout) in the U.S. The impact of finfish culture, for the block fish market, should be especially favorable because it also seeks to displace imported products.

\section{Beneficial Aspects of Using Waste Heat for Aquaculture}

Some of the more important fish growth parameters include water temperature, dissolved oxygen content, diet and waste product concentrations. Water temperature is extremely important because the metabolic activity, hence growth rate, is directly related to the water temperature. This relationship (adapted from growth curves in Refs, 8 and 9) is 1llustrated in Fig. 1 for two species.

Although the growth curves in Fig. 1 are for the species indicated, the general trend Indicated by these curves is applicable to all species. It is evident, from Fig. 1, that an optimal growth temperature (or temperature range) is preceded and succeeded by a range of declining growth rate. It is also apparent that there exists a minimum and maximum temperature beyond which growth ceases, or becomes extremely small.

At the present time, commercial catfish production is limited in many areas of the U.S. by cool water temperatures during winter months. During these months the fish grow slowly or cease growth unt1l the water temperature begins to warm in the spring. Power plant waste heat could be utflized in this application to maintain an acceptable temperature level in the water to permit fish growth year round.

Potentially, the most beneficial use for power plant waste heat in aquaculture is to maintain optimal growing temperatures for the cultured species. By maintaining optimal growing temperatures the time required to produce a marketable product can be substantially reduced. Oysters, for example, can grow to a size comparable to the size of a natural oneyear-old oyster in six weeks to three months when reared in heated power plant effluent water. ${ }^{7}$ Similarly, lobsters can be grown to $0.45 \mathrm{~kg}$ (1 $\mathrm{lb}$ ) sizè in under 3 years by conlrulliug diet and water temperaturc.10 This 


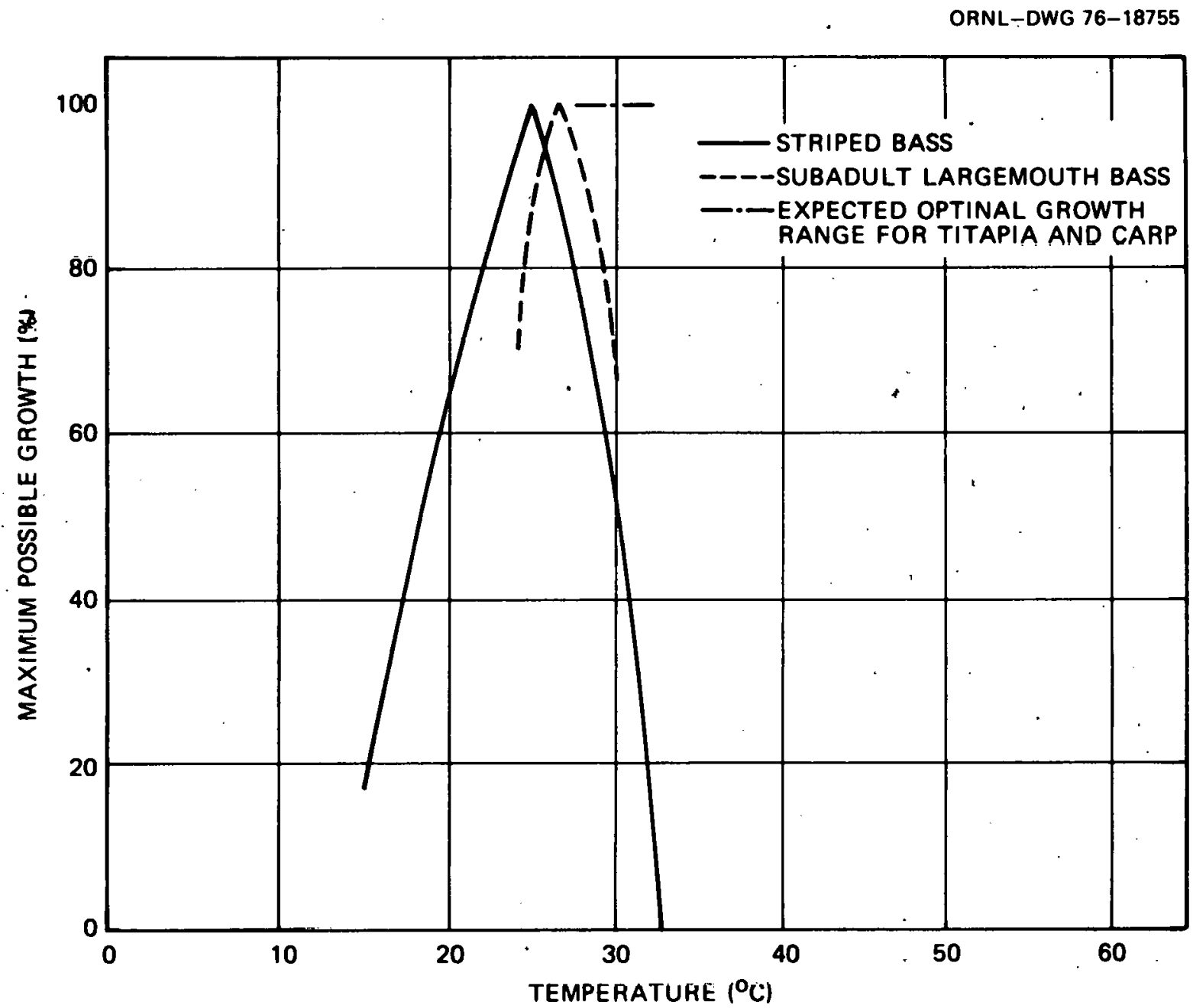

Fig. 1. Growth of striped and subadult largemouth bass as a function of temperature. 
compares to a normal time requirement of 6 to 7 years in their natural environment.

It is apparent from the above that a cheap source of heated water could have a significant impact on the aquaculture industry. By extending growing seasons and permitting maximum growth temperatures to be maintained, ylelds could be substantially increased. Power generating station waste heat could prove an excellent source for the required heat. Condenser outlet temperatures are generally within the optimal growth ranges for a great number of cultured species during most of the year. However, during the summer months, when the power plant effluent can reach $45^{\circ} \mathrm{C}$ $\left(115^{\circ} \mathrm{F}\right)$, heat addition, in large quantitles, may be required only for tropical species, such as tilapia, that are not now widely cultured in the U.S.

Since most new power generating facilities in the U.S. will now be required to use closed loop cooling systems, a series of cooling ponds or canals, that could be used for aquaculture, could be used for the. cooling system. Any portion of the waste heat that could be used for aquaculture would reduce the required size of the cooling tower and result in substantial savings to the utility.

For existing power stations the most direct application would be for plants using once through cooling systems or cooling ponds. In these applications, the aquatic crop could be placed directly in the condenser outfall. For existing power plants using cooling towers some modification in the condenser cooling loop would be necessary. However, this could be recovered by charging an appropriate fee to the waste heat user. It is apparent that there are essentlally no economic benefits for the utility to utilize waste heat from an existing station, unless they are able to sell the waste heat to the user. However, if the utillty owned and operated the aquaculture facility, they could derive significant economic benefit from utilizing thej.r waste heat to promote fish growth. Alternatively, the utility could rent the land to an aquaculture facility and provide them free heat. Even if the utility derived no economic benefit, the favorable publicity generated by use of power plant waste heat to produce food would be of great value to the utility. 
SUMMARY OF CURRENT RESEARCH AND COMMERCIAL EFFORTS IN WASTE HEAT AQUACULTURE

At the present time, research and commercial efforts in waste heat aquaculture are directed at high-priced, gourmet-type species. Lobster, oysters, fresh- and salt-water shrimp, and salmon are the species favored in present systems. This section will present a summary of the status of these projects. Detafled information on several of these ventures can be found in Appendix $A$.

Marine shrimp culture is presently faced with major technological. problems concerning spawning in captivity. This has resulted in unfavorable economic conditions related to obtaining larvae for stocking. Lobster culture is, at present, commercially unattractive because of high feed costs and the relatively long growth time required. Although salmon farmers must now contend with disease problems, large-scale production may prove profitable. It is interesting to note that the most successful waste heat aquaculture ventures, namely, oyster culture, are those that provide a minimum of supplemental feed. Since high protein commercial feeds can represent as much as $50 \%$ of operating costs, 11 it is apparent that a reduction in feed costs is highly desirable to achiovo coonomie feasibility in an aquaculture venture. It is this situation that leado to consideration of a new approach to waste heat aquaculture.

PROPOSED WASTE HEAT AQUACULTURE SYSTEM

The aquaculture system proposed in this report utilizeo fin and shellfish that feed on the lower trophic levels of the food chain. Addition of waste heat is used to provide regulated growth temperatures for phytoplankton and zooplankton and the fin and shellfish cultures. Planktonic growth is further enhanced by the addition of nutrients (e.g. carbon, nitrogen, and phosphorous) available from a variety of waste water streams.

The planktonic biomass is used as the food source for the fish culture, thus ellminating the need for supplemental feeding. Polyculture techniques are employed in the finfish culture to utilize all feeding niches in the pond. 
Benefits of Culturing a Herbivorous Aquatic Species

From the previous discussion it is evident that aquaculture systems utilizing existing ecosystem food supplies are more economically attractive than those that require commercial feeds. Species that are most desirable, from this aspect, are filter feeding shellfish and herbivorous finfish. These species generally consume the lowest trophic levels in the planktivorous food chain; namely, microscopic algae and zooplankton. Even though these species are not generally considered delicacy items (oysters and possibly clams being the exception), which would command a high market price, a venture of this type possesses the potential for success because of low operating costs involved. Essentlally, this type of system is directed at producing aquatic animal protein at the lowest possible cost.

Another aspect that makes a low-cost protein facility attractive is that most delicacy items are marine species. This limits waste heat applications for culture of these species to coastal areas. In contrast, an aquaculture facility utilizing herbivorous species could utilize marine or fresh water species. Thus this system would possess greater potential for utilizing power plant waste heat from both coastal and inland power stations.

A low-cost protein aquaculture system is preferable, from a potential use for waste heat viewpoint, for several other reasons. 'Because this type of system is directed at satisfying basic protein requirements of the general populace at a reasonably low price, rather than appealing to a small section of the market that prefers expensive protein, the potential market is 1ikely to be larger than that for delicacy items. Additionally, many of the herbivorous fish, considered as likely candidates for aquaculture, are native to tropical climates. Therefore, when cultured in temperate climates, such as the U.S., it is expected that heat addition will be required, even in summer, to promote optimal growth. Therefore, the expected large potential market and required summer heat addition seem to make a low-cost aquaculture facility desirable in terms of potential waste heat use. 


\section{Proposed System Description}

Alternative biological systems proposed for a waste heat aquaculture facility producing low-cost protein have been based on the following assumptions: (a) a minimum temperature of $20^{\circ} \mathrm{C}\left(68^{\circ} \mathrm{F}\right)$ can be maintained through the year, (b) a controlled input of nutrients (carbon, nitrogen and phorphorous) is avallable, (c) mud bottomed ponds, 1 to $2 \mathrm{~m}$ ( 3 to $6 \mathrm{ft}$ ) deep, are used. Assumption (a) essentially envisions utilization of waste heat from a power plant using a closed $1 \mathrm{nnp}$ rnnling system. For this preliminary study the species selection concentrated on fresh water varleties because the majority of power plants, especially nuclear plants, are located inland. It should be noted, however, that suitable species (such as striped mullet, croaker, tarpon and sheepshead) are available for coastal sites.

There are any number of waste streams that could satisfy the nutrient requirements outlined in assumption (b). Candidates for use in the proposed system include domestic sewage, cattle feedlot wastes, swine and chlcken manure, and some Industrial waste streams (e.g. brewery or fertilizer plant waste water). For this study the nutrient source is assumed to be domestic secondary sewage effluent.

The basic physical design of the system is the same for all species associations and is schematically outlined in Fig. 2. Conceptually, the system functions in the following manner. Stabilized secondary sewage effluent is heated using power plant waste heat and flows into Pond I with an appropriate amount of power plant effluent, which is used as a diluent. Algae begin the uptake of nutrients, in Pond $I$, and are grazed upon by zooplankton. The overflow from Pond I, laden with algae and zooplankton, flows into Pond II where fish are grown. In Pond II fish consume algae, zooplankton, aquatic macrophytes (grown in the pond mud bottom) and benthic organisms. Water flows into Pond III laden with fish waste products and algae are again used to remove the nutrients. In Pond IV clams are used as living biofilters; straining algae and bacteria out of the water, producing a clean effluent. Crayfish are used in Pond IV to consume the clam wastes. Protein production is, therefore, concentrated in fish, clams, and crayfish. 
ORNL-OWG 76-18756

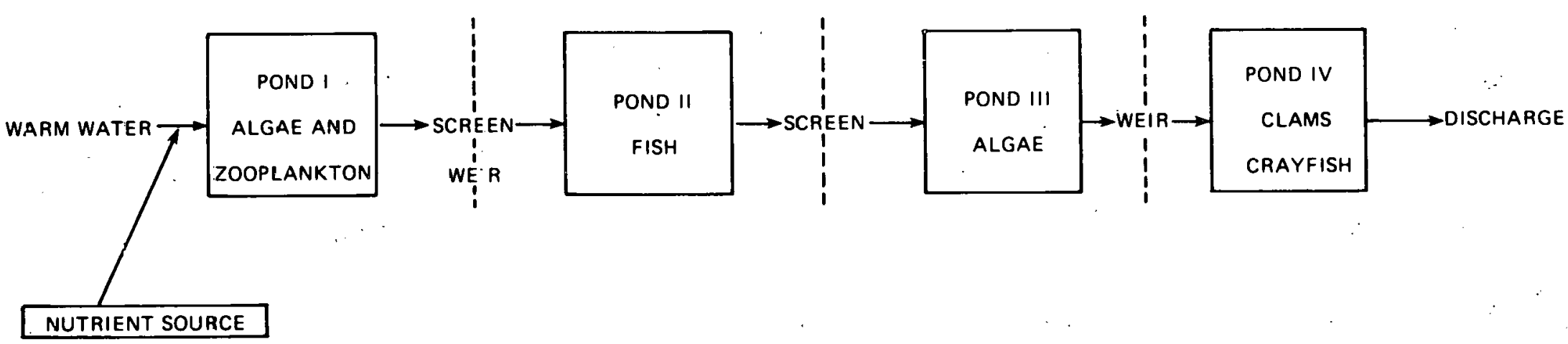

Iig. 2. Schematic diagram of proposed waste heat aquaculture system. 
Harvesting is accomplished with the aid of pond drains in the bottom of the ponds. If the aquaculture facility is large enough to support a processing plant, the pond can be drained directly to the processing plant, thus eliminating a great deal of fish handling. If the fish are to be transported to another location for processing, the drains can be screened off and when the pond is lowered the fish can be seined. The clams can be cultured on trays. Therefore, harvesting will be accomplished by hauling the trays from the pond and removing the clams.

The algae and zooplankton growth ponds (Ponds I and III) are plastic lined to permit mixing and prevent increases in water turbidity because of disturbances on a mud bottom. The fish and clam ponds are mud bottom to allow rooted aquatic vegetation, which is used as food by the fish, to grow and because they are less expensive than lined ponds.

The alternative blological associations for culture in Pond II are outlined in Table 1. For each assoclation the species involved is listed along with their feeding niche and the name by which they are commonly known.

\section{System Performance Estimates}

A lack of certain basic biological information (optimal growth rate data, feed conversion efficiency, etc.) concerning most of the species selected, coupled with unknown system synergistic effects, precludes a sophisticated determination of the performance of the proposed system. Data from various studies by well known researchers, related to the individual elements of the overall system, have been used to estimate the sewage requirements, heat rejection capability, and protein production of the system. Since the proposed system functions as a series of independent systems (1.e., an algae growth system followed by a fish growing system), it is expected that the results of these studies are Indicative of the overall performance of the low-cost protein facllity.

\section{Production estimates}

Reliable data on carp polyculture yields indicate that under favorable circumstances, in the Far East, 7500 to $8000 \mathrm{~kg} / \mathrm{ha}$-year (6600 to 
Table 1. Species assoclations for the proposed waste heat aquaculture system

\begin{tabular}{lll}
\hline Alternative & Species & Primary feeding niche \\
\hline
\end{tabular}

1. Carp association

Grass carp

Bighead carp

Silver carp

Mud carp

Common carp

Black carp

2. Tilapia association

Nile tilapla

Java tilapia

Blue tilapia

Congo tilapia

3. Indigenous association

Channel catfish Buffalo

Congo tilapia

Common carp
Ctenopharyngodon idellus Aristichtys nobizis Hypophthalmichtys molitriy

Cirshinus molitorella

Cyprinus carpio

MyZopharyngdon piceus
Large floating plants Midwater zooplankton Phytoplankton in midwaters

Bottom feeder, feces Bottom feeder Mollusks
Tilapia nilotica

Tilapia mossambica

Tilapia aurea

Tilapia rendalli

(T. melanopleura)
Omnivorous (esp. plants) Omnivorous (plankton) Plankton
Rooted aquatic vegeta- tion

Ictalums punctatus Ictiobus sp. Tilapia rendalli Cyprinus carpio
Omnivorous Benthic feeder Aquatic vegetation Benthic feeder 
7050 1b/acre-year) may be obtained using pond culture techniques. 12 Carp culture in India, 13 using cow manure for pond fertilization, has ylelded $6521 \mathrm{~kg} / \mathrm{ha}$-year ( $5745 \mathrm{lb} / \mathrm{acre}$-year). During these experiments the water temperature was in the range of $19.5-35.5^{\circ} \mathrm{C}\left(67-96^{\circ} \mathrm{F}\right)$. Since water temperature will be controlled to promote optimal growth, an expected yleld of $7375 \mathrm{~kg} / \mathrm{ha}$-year (6500 1b/acre-year), was assumed for the carp culture.

Studies in Taiwan ${ }^{14}$ have shown that tilapia production from ponds that had been richly fertilized with sewage water had reached 6500 to $7500 \mathrm{~kg} / \mathrm{ha}$-year (5725-6600 1b/acre-year). It was also determined that ponds using only a moderate amount of sewage water produced 3500 to $5000 \mathrm{~kg} / \mathrm{ha}$-year. (3083 to $4400 \mathrm{lb} /$ acre-year). For the purposes of this study it was assumed that sewage effluent avallability would not be limiting. Thus a production estimate of $7375 \mathrm{~kg} / \mathrm{ha}-y e a r(6500 \mathrm{lb} / \mathrm{acre}-$ year) was assumed.

It was difficult to establish an expected production for the third association because it is highly dependent on stocking densities of the various species, and production figures are not available for a similar association. For the purposes of this study, it was assumed that a production of '2270 kg/ha-year (2000 1b/acre-year)' was reasonable.

Clam culture production yields are not readily avallable, therefore, uysler culcure yields were used as the basis for estimating production. A study at Woods Hole Oceanographic Institute 15 indicated that, under proper temperature conditions, nyster meat produotion could reach $417,680 \mathrm{~kg} / \mathrm{ha}$-year (184 tinns/acre-year). Thcae results were ollulued for oysters grown on trays in aerated raceways which were fed algae grown using secondary sewage effluent. Since pond culture will be used instead of raceways, it was felt that an annual clam meat production of $1.3 \times 10^{5} \mathrm{~kg} / \mathrm{ha}$ (50 tons/acre) was reasonable.

Since the crayfish feed, primarlly, on clam waste, the production rate for the crayfish may be limited by the clam production rate. Studies ${ }^{15}$ have shown that clams excrete some 30 to $70 \%$ of the nutrients supplied in their feed. Assuming a waste generation of $50 \%$ of the food supplied, it is evident that clam meat and waste production will be equal. Assuming a $10 \%$ feed conversion efficiency (which is typical for 
protein conversion from one trophic level to the next highest) for the crayfish yields, a maximum sustainable crayfish production of about $10 \%$ that of the clams or $11,350 \mathrm{~kg} /$ ha-year $(10,0001 \mathrm{~b} /$ acre-year $)$. Typtcal ylelds from Louisiana crayfish growers show that well-managed ponds commonly produce 400 to $700 \mathrm{~kg} / \mathrm{ha}$-year (350 to $615 \mathrm{lb} / \mathrm{acre}-y e a r$ ) with yields of slightly better than $1100 \mathrm{~kg} / \mathrm{ha}$-year (970 1b/acre-year) being maximum. ${ }^{11}$ From the above discussion, it is evident that a crayfish yield of $1100 \mathrm{~kg} / \mathrm{ha}$-year $(970 \mathrm{lb} / \mathrm{acre}$-year) can be sustained and this was used in the study.

\section{Sewage and land requirements}

The land and sewage requirements for the proposed system are essentrally determined by the size of the fish and clam ponds. Once these have been specified the algae requirements, hence the algae pond sizes and sewage required, can be calculated. For the purposes of this study it was assumed that the fish and clam pond produced negligible amounts of algae. Therefore, all algae production was accomplished in the algae growth ponds.

To make the results applicable to aquaculture facilities of various sizes, the land and sewage requirements have been computed on a per unit annual production basis for both the fish and clam culture. Detalls will be presented to demonstrate how these figures were determined for the carp or t1lapia culture and for the clam culture.

For the purposes of this study it was assumed that the fish pond was 0.2 ha $(1 / 2$ acre) and the clam pond 0.05 ha $(1 / 8$ acre). These stzes were chosen because commercial experfence has indicated that larger ponds are sometimes difficult to manage and harvest. Use of smaller ponds also minimizes the impact and potential loss due to disease problems. Since the grower can isolate the infected pond while attempting to cure the afflicted animals, only a small portion of the crop is affected.

A series of smaller ponds is also advantageous when attempting to supply fresh products on a year-round basis. Since harvesting stresses the animals and increases their susceptibility to disease, it is desirable to harvest an entire pond at one time. By stocking the ponds according 
to an appropriate timetable, weekly fresh fish and clam demands can be met by harvesting a selected number of ponds.

The annual fish production from this system is $1474 \mathrm{~kg} /$ year ( $3250 \mathrm{lb} /$ year), and the annual clam meat yield is $5670 \mathrm{~kg} /$ year. $(12,500 \mathrm{lb} /$ year). This ylelds an average dafly growth of $4.1 \mathrm{~kg} / \mathrm{day}$ (9.0 1b/day) for the fish and $14.7 \mathrm{~kg} /$ day $(32.4 \mathrm{lb} /$ day $)$ for the clams. Assuming an average food conversion effictency of $10 \%$ for the fish and, as previously mentioned, $50 \%$ for the clams, the daily algal requirements are $40.8 \mathrm{~kg} / \mathrm{day}(90 \mathrm{lb} / \mathrm{day})$ for the $\mathrm{fish}$ and $29.4 \mathrm{~kg} / \mathrm{day}(64.8 \mathrm{lb} / \mathrm{day})$ for the clam culture. Boersma ${ }^{16}$ has shown that an average algal production rate of $30 \mathrm{~g} / \mathrm{m}^{2}$-day $\left(6.2 \times 10^{-3} \mathrm{lb} / \mathrm{ft}^{2}\right.$-day $)$ is possible throughout the year. Therefore, 0.13 ha $(0.33$ acre) of algal pond surface area is required to support the fish culture and 0.10 ha $(0.25$ acre) for the clam culture. These land requirements on a per annual output basis are $0.9 \mathrm{~m}^{2} / \mathrm{kg}\left(4.4 \mathrm{ft}^{2} / 1 \mathrm{~b}\right)$ for the $\mathrm{fish}$ culture and $0.18 \mathrm{~m}^{2} / \mathrm{kg}\left(0.9 \mathrm{ft}^{2} / 1 \mathrm{~b}\right)$ for the clams.

The sewage requirements can be calculated knowing the amount of algae needed and the nitrogen content of the secondary sewage effiuent. Studies 17 have shown that for each unit weight of algae grown 0.1 units of nitrogen and 0.01 untts of phosphorus are required. It has also been shown that an algal culture is capable of removing almost all of the nicrogen trom the sewage effluent under ideal conditions.16,18 Therefore, an average yearly nitrogen removal efficiency of $90 \%$ has been assumed. Using a typical secondary effluent nitrogen content of $0.03 \mathrm{~g} / 1$ $\left(2.5 \times 10^{-4} \mathrm{lb} / \mathrm{gal}\right)$ yields sewage requirements of $0.1 \mathrm{~m}^{3} / \mathrm{day} / \mathrm{kg}$ of $\mathrm{ftah}$ (12.1 gal/day/lb of fish production) for the fish system and $0 . n 2^{3} \mathrm{~m} / \mathrm{day} / \mathrm{kg}$ (2.4 gal/day/1b) for the clam culture. Using a per capita sewage production of $0.42 \mathrm{~m}^{3} / \mathrm{day}$ (110 gal/day), the population required to support the fish culture is 0.24 people/kg of $\mathrm{fish}$ production $(0.11$ people/lb of $\mathrm{fish}$ ) and for the clam system is $4.9 \times 10^{-2}$ people/kg of clam meat (2.2 $2 \times 10^{-2}$ people/1b of clam meat).

'lhe land and population requirements for a system using $a .2$ ha ( $1 / 2$ acre) fish pond and $a .05$ ha ( 0.8 acre) clam culture are summarized in Table 2 for the associations described in Table 1. Also shown in 
Table 2 is the population required to provide the necessary sewage effluent.

Table 2. Land and sewage requirements for a complex consisting of $a .20$ ha fish pond and $a .05$ ha clam pond

\begin{tabular}{lcccc}
\hline $\begin{array}{c}\text { Fish } \\
\text { association }\end{array}$ & $\begin{array}{c}\text { Algal pond area } \\
\text { (ha) }\end{array}$ & $\begin{array}{c}\text { Total area } \\
\text { (ha) }\end{array}$ & $\begin{array}{c}\text { Sewage effluent } \\
\left(\mathrm{m}^{3} / \text { day }\right)\end{array}$ & Population \\
\hline Carp & 0.23 & 0.48 & 266 & 633 \\
Tilapia & 0.23 & 0.48 & 266 & 633 \\
Indigenous & 0.15 & 0.40 & 162 & 385 \\
\hline
\end{tabular}

Potential for waste heat dissipation

Boersma ${ }^{19}$ has experimentally determined heat losses from algal growing ponds held at $35^{\circ} \mathrm{C}\left(95^{\circ} \mathrm{F}\right)$ in Oregon. His results indicate an average summer heat loss of $699 \mathrm{~W} / \mathrm{m}^{2}\left(222 \mathrm{Btu} / \mathrm{hr}-\mathrm{ft}^{2}\right)$ and a winter heat loss of $1465 \mathrm{~W} / \mathrm{m}^{2}\left(465 \mathrm{Btu} / \mathrm{hr}-\mathrm{ft}^{2}\right)$. The system outlined in the previous section requires 0.48 ha ( 1.2 acres) of pond area. It is therefore capable of dissipating $3.4 \mathrm{MW}\left(11.7 \times 10^{6} \mathrm{Btu} / \mathrm{hr}\right)$ of power plant reject heat in the summer and $7.2 \mathrm{MW}\left(24.6 \times 10^{6} \mathrm{Btu} / \mathrm{hr}\right)$ in the winter. Although these heat loss results apply to weather conditions in Oregon, they can be extrapolated to other climates using prevalling meteorological data.

In order to reject all the power plant waste heat from a $1000-\mathrm{MW}(e)$ power plant during the summer in Oregon, 238 ha (589 acres) of pond surface would be required. This complex would include 23.8 ha ( 58.9 acres) of clam ponds and 100 ha (247 acres) of fish ponds. Full production from the system would be $2.7 \times 10^{6} \mathrm{~kg} /$ year $\left(5.9 \times 10^{6} \mathrm{lb} /\right.$ year $)$ of clam meat, $7.4 \times 10^{5} \mathrm{~kg} /$ year $\left(3.3 \times 10^{5} \mathrm{lb} /\right.$ year $)$ of 1 ive fish and $2.6 \times 10^{4}$ $\mathrm{kg} /$ year $\left(5.7 \times 10^{4} \mathrm{lb} /\right.$ year $)$ of live crayfish. However, since the winter heat loss is greater than that during the summer, full production of the complex in winter would not be possible due to insufficient heat aval1able from the power plant. If the aquaculture faclitity was instead designed for full production, using the heat avallable during winter, 
the complex would contain 133 ha (329 acres) of pond area. This complex would provide tertiary sewage treatment for a city of about 170,000 people. Production from this system would total $4.1 \times 10^{5} \mathrm{~kg} /$ year $\left(9.0 \times 10^{5} \mathrm{lb} /\right.$ year $)$ of $\mathrm{fish}, 1.5 \times 10^{6} \mathrm{~kg} /$ year $\left(3.3 \times 10^{6} \mathrm{lb} /\right.$ year $)$ of clam meat and $1.5 \times 10^{4} \mathrm{~kg} /$ year $\left(3.3 \times 10^{4} \mathrm{lb} /\right.$ year $)$ of live crayfish. During the summer months the pond system would not be sufficient to dissipate all the power plant waste heat but could accommodate about $47 \%$ of the summer load. Thus the installed cooling tower capacity could be reduced, resulting in significant savings to the utility.

From the above discussion, it is evident that the 8138 of the aquaculture facility affects the operation of the aquaculture system and the required cooling tower capacity. If the aquaculture facility is designed to maintain full production during the year, cooling towers must be constructed to accommodate about $53 \%$ of the summer heat rejection load. If the aquaculture facility is instead sized to accommodate the entire summer heat load, no cooling tower capacity (except perhaps as a backup system). is required. However, insufficient heat from the power plant in winter will necessitate a reduction in protein production. If optimum growing conditions are to be maintained during winter, approximately $44 \%$ of the ponds must cease production. If less than this number cease operation, the result will be suboptimal growing temperatures in the production ponds. However, the increased number of ponds in operation may override the decreasing growth rate and prove to be the economic choice.

The economically optimum situation, therefore, involves a trade-off between the capital costs for conling towers and ponds and the income from the sale of aquaculture products. This analysis shnuld he performed at each location under consideration since many of the economic parameters will be site specific.

As stated previously, an ideal market for the fish raised in this system would be the block flsh market. Assuming $25 \%$ of the live weight. is processing waste, the fish production of the 133 ha ( 329 acre) complex would satisfy about $0.5 \%$ of the block fish imports. Since it would require on the order of 200 such facilities (each in conjunction with a $1000 \mathrm{MW}(\mathrm{e})$ power plant) to satisfy only the block fish market, it is 
apparent that the potential for this system to utilize power plant waste heat is very large.

\section{Economic Analysis}

Because the production figures are estimated ylelds the economic analysis for this system is of a preliminary nature. As a baseline figure, the economic analysis was performed for a single 0.48 ha $(1.2$ acre) module given the following assumptions:

1. The power company does not charge for the waste heat but does rent the land to the fish grower for $\$ 74 /$ ha $(\$ 30 /$ acre).

2. The aquaculture system is close to the waste heat source, therefore no piping or pumping charges have been included.

3. A sewage treatment plant is in close proximity, and there is no cost to obtain secondary sewage effluent.

4. Pond construction is accomplished by having bulldozers pushing dirt to form a levee. Costs for this type of construction are presently about $\$ 1,324 /$ ha $(\$ 535 /$ acre $) .20$ Also, algal growing ponds are lined with a plastic liner to provide a hard surface.

5. Operating costs are similar to those of catfish pond operators in the U.S.

6. Small $187 \mathrm{~W}(1 / 4 \mathrm{hp})$ pumps are used in the algal ponds to promote mixing. Operating efficiency for these pumps is $70 \%$.

7. Interest on invested capital is $83 / 4 \%$. Depreciation is accounted for using a sinking fund at $83 / 4 \%$ over a 20 -year period.

8. Heat is transferred from the power plant cooling water to the sewage effluent through a plastic heat exchanger to avold heavy metal buildup in the shellfish.

It was felt that assumption 3 was reasonable because no credit has been taken for providing municipal tertiary sewage treatment. This credit would likely be sufficient to pay for any expense involved in transporting the effluent to the aquaculture site. Also, no piping or pumping charges, associated with using the heat contained in the condenser cooling water, have been assessed because these costs would depend on the size of the 
aquaculture facility and the layout of the system. Since the economic estimate is being performed for a single module, it can be located close to existing piping and simply tap into the existing pipe route.

For applications where a large aquaculture facility is employed, piping and pumping costs, associated with distributing the waste heat to the ponds, should be included. However, these applications would utilize a significant portion of the power plant reject heat. The aquaculture facility, which essentially functions as a cooling pond, would replace a portion of the cooling tower (or ponds) capacity required to dissipate the refect heat. Since this would result in substantial cost savings for the utility, it is likely that they would finance the waste heat distribution system.

The plastic heat exchanger was designed to transfer $8787 \mathrm{~kW}$ $\left(30 \times 10^{6} \mathrm{Btu} / \mathrm{hr}\right)$ to the sewage water. An overall heat transfer conductance of $369 \mathrm{~W} / \mathrm{m}^{2}-^{\circ} \mathrm{C}\left(65 \mathrm{Btu} / \mathrm{hr}-\mathrm{ft}^{2}-^{\circ} \mathrm{F}\right)$ and a $10 \mathrm{~g}$ mean temperature difference of $5.7^{\circ} \mathrm{C}\left(10.2^{\circ} \mathrm{F}\right)$ were also used. The heat exchanger material is a polyprophlene copolymer in the form of an extruded honeycomb with flow channels of sufficient size. The material cost for ultraviolet radiation inhibited material, impregnated with carbon black, is $\$ 1.90 / \mathrm{m}^{2}$ $\left(\$ 0.24 / \mathrm{ft}^{2}\right)$. A fabricated heat exchange cost of $\$ 8.07 / \mathrm{m}^{2}$ of heat exchange area $\left(\$ 0.75 / \mathrm{ft}^{2}\right)$ was, therefore, used in this study.

labie 3 summarizes the estimated capital costs for the 0.48 ha (1.2 acre) aquaculture system. It is evident that the greatest cost item is the heat exchanger. If the power plant conling water rnuld be mixed with the sewage effluent, thus eliminating the need for an intermediate heat exchanger, substantial savings could be realized.

Table 4 details the estimated annual costs for the proposed aquaculture system. It is clear that the major cost item is the annual cost associated with the heat exchanger investment.

In estimating the income derived from sale of the fish, clams, and crayfish, it was assumed that the products were sold live to processors or wholesalers. It was also assumed that the fish products are eventually processed into frozen block filet.

Table 5 detalls the expected income and profit from the alternate associations proposed in Table 1 . It is evident that the potential 
Table 3. Capital cost summary for a 0.48 ha module

\begin{tabular}{lr}
\hline \multicolumn{1}{c}{ Item } & \multicolumn{1}{c}{ Cost } \\
\hline Ponds & $\$$ \\
Pumps (2 @ \$100 ea) & 650 \\
Weirs and screens & 200 \\
Installed pond 11ner & 120 \\
Fish handling and grading equipment & 5,875 \\
Subtotal & 500 \\
Contingency (@30\%) & 7,345 \\
Heat exchanger & 2,203 \\
$\quad$ Total & 32,250 \\
\hline
\end{tabular}

Table 4. Annual cost summary for a 0.48 ha module

\begin{tabular}{lc}
\hline \multicolumn{1}{c}{ Item } & Annual cost \\
\hline Investment and operating costs & \\
Interest on investment capital & $\$ 3,650$ \\
@ 8 3/4\% & 914 \\
Depreciation & 160 \\
Labor and management & 49 \\
Insurance, taxes, etc. & 12 \\
Repairs and maintenance & 36 \\
Land rent & 94 \\
Electricity @ \$0.02/kWhr &. \\
Stocking costs & 420 \\
Fioh fingerlinge @ \$0.03 ea & 500 \\
Seed clams & 190 \\
Crayfish @ $\$ 0.03$ ea & $\$ 6,025$ \\
Total & \\
\hline
\end{tabular}


Table 5. Estimated income and profit from a 0.48 ha module

\begin{tabular}{|c|c|c|}
\hline & . & Revenue \\
\hline \multicolumn{3}{|c|}{ For carp or tilapia association } \\
\hline $\begin{array}{l}\text { Fish @ } \$ 0.66 / \mathrm{kg} \\
\text { Clams e } \$ 1.34 / \mathrm{kg} \text { of clam meat } \\
\text { Crayfish @ } \$ 2.75 / \mathrm{kg}\end{array}$ & $\begin{array}{l}(\$ 0.30 / 1 b) \\
(\$ 4.38 / b u) \\
(\$ 1.25 / 1 b)\end{array}$ & $\begin{array}{r}\$ 975 \\
8,680 \\
152 \\
\end{array}$ \\
\hline Total revenue & & $\$ 9,807$ \\
\hline Total annual cost & & $\underline{6,025}$ \\
\hline Net profit & & $\$ 3,782$ \\
\hline \multicolumn{3}{|c|}{ For indigenous assoclation } \\
\hline $\begin{array}{l}\text { Fish @ } \$ 0.66 / \mathrm{kg} \\
\text { Clams e } \$ 1.34 / \mathrm{kg} \text { of clam meat } \\
\text { Crayfish } \$ 2.75 / \mathrm{kg}\end{array}$ & $\begin{array}{c}(\$ 0.30 / 1 \mathrm{~b}) \\
(\$ 4.38 / \mathrm{bu}) \\
(\$ 1.25 / 1 \mathrm{~b})\end{array}$ & $\begin{array}{r}300 \\
8,680 \\
152 \\
\end{array}$ \\
\hline Total revenue & & $\$ 9,132$ \\
\hline l'otal annual cost & & 6,025 \\
\hline Net profit & & $\$ 3,107$ \\
\hline
\end{tabular}

profit from the carp or tilapla association is larger than for the indigenous association because of the larger fish production. However, all associations do show a profit potential. It should be noted that although the expected yields, hence income, are smaller than those common to intensive aquaculture methods, the proposed systems are economically viable. This is because the major cost items (capital intenstve rareway systems, high protein feed and required labor intensive management techniques) are circumvented by using an aquatic system that feeds on the lower levels of the food chain. If the fish required commercial feed, approximately $\$ 5,300$ would be added to the annual cost. This would increase the annual costs to a point that would make the system economically unattractive.

The projected profits detalled in Table 5 are for a single 0.48 ha (1.2 acre) module. The annual pretax profit from an aquaculture operation, in confunction with a 1000-MW(e) power plant, sized for full production during the winter ( $1 . e ., 133 \mathrm{ha}$ ), would be on the order of $\$ 1.05$ million $-\cdots$ 
for a carp or t1lapia association and $\$ 860,000$ for the indigenous association. If the tilapia or carp could occupy a higher position in the market (i.e., sold as fillets rather than for blocks), the price received for them could concelvably double. This would raise the projected annual profit from a 133 ha (329 acre) farm to $\$ 1.85$ million.

It should also be noted that, for some applications, the intermediate plastic heat exchanger could be eliminated. The heat exchanger essentially prevents the pond water from being contaminated by heavy metal concentrations and chemicals that may be present in the condenser cooling water. It also isolates the pond water from any radionuclides that may be present in the cooling water flow.

The present trend in power plant condenser design is to use thin wall titanium condensers. Since titanium is essentially noncorroding, problems associated with heavy metal concentrations in the cooling waters are eliminated.

Therefore, if the aquaculture system was to use heat from a fossil plant that had a titanium condenser, the plastic heat exchanger could be eliminated. This would result in a capital saving that would increase the profit potential substantially.

\section{Discussion of Possible Problems and Benefits}

Perhaps the most serious potential problems are a result of using secondary sewage effluent as the primary nutrient source. The major area of concern is that viruses and heavy metals, which may persist through all stages of treatment, may concentrate in the fish and clams. At present, virologists are not in agreement concerning viral disease transmission to humans through the products of such a cycle. To this date, there have been no reported instances of human viral disease from aquatic products grown using sewage, even though the practice is extensively used in India, ${ }^{12}$ China, 12 Taiwan, 14 and other Astan and African countries. A virologist working with the group at Woods Hole Oceanographic Institute that is growing oysters, using sewage grown algae, feels that the virus question will not be serious and can be resolved within the time scale of the present experiments.18 One solution to the problem would be to use 
an ozonization process on the sewage effluent to k1ll the viral transmission organisms.

Heavy metal concentration is expected to be a serfous problem only in areas that mix industrial and municipal wastes. Heavy metals and other toxic substances from industrial wastes would be concentrated in the clam meat, and toxins that made their way through the treatment system might create health hazards for consumers or poison the aquaculture facility itself. However, new regulations are likely to lead to separation of industrial and municlpal wastes. Such regulations would help ensure the quality and safety of an aquaculture facility and alleviate the heavy metal uptake problem.

Another possible problem is that the fish are unfamiliar, in the case of tilapia, or may be considered unacceptable (e.g., carp) by the U.S. consumer. However, with proper marketing it is probable that these species could achieve a popularity in the U.S. that they enjoy elsewhere in the world. At the present time these two specles are the most widely cultured in the world 12 and provide much needed protein to a substantial number of people. In some African and South American countries tilapla occupy a "delicacy" position in the market because of their taste and their ability to live for long periods out of the water. Hence they can be sold live at markets distant from where they are raised.

In an effort to make carp more popular, much research has been done to improve the product quality. These high quality carp strains have generally been developed by systematic selection.21. Hybridization of various carp species has led to strains with smaller heads and higher dressed weight, as well as strains with reduced fat content. 21 Work has also begun to develop a "boneless" variety to ellminate the fine intramuscular bones that impede consumer acceptance.

Unfamillarity of tilapia in the market is not expected to be a serious problem because they are being sold in the U.S., in limited quantity, at the present time. 22 They are being marketed in the Southeast as frozen, cleaned fish with heads and talls still attached. At the present time they are selling for about $\$ 2.20 / \mathrm{kg}(\$ 1.00 / 1 \mathrm{~b})$ and are generally sold under the name Nile Perch. If sufficient quantities were avallable, a suitable marketing campaign could increase the popularity of tilapia 
significantly. Therefore, it is expected that, since the product quality of carp is continually being improved and carp and tilapia are popular throughout the world, potential consumer acceptance problems in the U.S. can be overcome:

Tilapia have been shown to be prolific breeders when cultured, in ponds. In fact, it is difficult to prevent them from breeding. Because of this, tilapia cultures tend to become overpopulated and result in stunted growth in the culture. Since fish consumers generally prefer larger fish, a commercial tilapla venture would be required to find a method to control breeding. The most successful method of controlling breeding is to raise a monosex culture. Presently there are three cross breeds that produce $100 \%$ male populations, and work is being performed to find suitable crosses which w11l produce all females.12 Therefore, it is expected that overpopulation problems will be circumvented and fish of sultable size can be produced by using one of the existing male monosex cultures.

Although the clam culture filters the water in Pond IV, residual fish and clam wastes, as well as unfiltered algae, may cause the effluent from Pond IV to violate the regulations governing discharges from such facilities. If this appears to be a problem, a small pond can be constructed to act as a settling basin for the effluent from Pond IV. Aquatic macrophytes, such as hydrilla, duckweed, or water hyacinth, can be used in this pond to remove any nutrients in the water and provide a clean effluent from the system. The effluent could then be routed to a recelving body of water or be used for cooling water makeup. The aquatic plants could be harvested and fed to the fish in Pond II.

The dependence on power plant waste heat can pose operational problems for the aquaculture facility, if the power plant is shut down due to an outage. Short periods (on the order of several hours) without heat can be tolerated, since heat stored in the ponds would be sufficient to maintain a reasonable growing temperature for the crop. However, loss of heat for an extended period, especially during cold weather, would retard or halt growth and could result in a large portion of the crop being killed. 
The problem of a rellable heat source for the aquaculture facility could be solved by siting the aquaculture facility at a multiunit power station, or by installing a water heater as a backup system. A multiunit station would provide a very reliable source of waste heat, since it is unlikely that all units would experience an outage at the same time. Additional piping would probably be required to provide the capability of using waste heat from each unit in the power station. Costs for this piping would be site dependent and could be borne by the power company, If the aquaculture facility used a significant portion of the waste heat.

If the aquaculture facility was sited at a single unit station; a backup water heater would probably be required. For an aquaculture system utilizing all the waste heat from a 1000-MW(e) plant, during winter, the water heater, sized to provide optimal growing conditions would be required to supply approximately $2 \mathrm{MW}(\mathrm{t}) \cdot\left(6.8 \times 10^{9} \mathrm{Btu} / \mathrm{hr}\right)$. A hot water heater of this size would cost on the order of $\$ 4$ million. This investment, recovered at $83 / 4 \%$ over 20 years, would increase operating cost by $\$ 400,000$ but would still result in an annual gross profit of approximately $\$ 600,000$.

If the aquaculture operator was willing to accept growth rates lower than optimal during a power plant outage, the ponds could be maintained at a lower temperature. This would result in a reduced capacity hot water heater being installed. The economic feasibility of this alternative depends upon the capital cost savings (resulting from a heater of reduced capacity being used), expected outage duration, and the economics of operating the system.

Using the aquaculture facility as a tertiary sewage treatment plant may cause operational problems concerning the sewage treatment. If the aquaculture system was to cease operation, the sewage effluent would not receive tertlary treatment. However, with the multiple module design used and provisions for a reliable heat source, it is very unlikely that a significant portion of the aquaculture facility would be inoperable. Therefore, it is expected that the aquaculture facility would be a reliable tertiary sewage treatment method.

Since the ponds will be maintained at a fairly constant temperature, the species of algae that will grow in the pond would not be expected to 
change during the year. Studies ${ }^{22}$ have indicated that as the water temperature changes the predominant species of algae in the pond changes. This changes the feeding habits of the cultured species and could have a detrimental effect on growth. By maintaining an algal culture with a constant predominant species, the diet of the fin and shellfish is constant and this promotes optimal growth.

The use of a polyculture system presents several advantages that would be beneficial to a commercial operation. All feeding niches are used in this system. Expecially attractive is the fact that wastes from some species are used as food by others. Using bottom feeders, to eliminate buildup of wastes, of ten eliminates the potential for fish products with an off-flavor. ${ }^{21}$ Using a polyculture system also provides flexibility in species selection that is not avallable in a monoculture system.

The system presented in this report is only one of many that may be suitable for a low cost protein production facility using waste heat. This system was chosen because each of the individual components has been investigated and shown to be technically feasible. Although this report has used a given set of parameters (i.e. nutrient supply, pond sizes, etc.), use of this, or a similar system, is not limited to the application studied. Indeed the system concept allows adaptation to fit site specific situations. Feedlot wastes, for example, could be substituted for sewage effluent if it were more readily avallable. Similarly, in areas when market conditions constrain production of either the fin or shellfish products, the product mix can be varied to meet these site specific conditions. The species selected can also be varied to meet market situations and local climatic conditions.

It is apparent, therefore, that the major expected problems can be overcome through proper management techniques and marketing efforts. It is also evident that in addition to producing reasonably priced protein and beneficially using power plant waste heat, tertlary sewage treatment is accomplished for nearby municipalities. 
SUMMARY AND CONCLUSIONS

Waste heat aquaculture in the U.S. has concentrated on high value specialty items such as shrimp, lobster, trout, salmon, and oysters. Because these species generally require high cost, high protein feeds, production costs are high. To reduce the unit production costs high yields are required. This results in intensive monoculture techniques being used. These techniques require large capital investments (for raceways, oxygenation systems, etc.) and have high nonfeed operating costs because they are labor intensive. Production of these species 18 , at present, marginally economical and is highly dependent on feed costs. If feed costs were to rise significantly, most operations would probably not be economically feasible.

Since the products appeal to the high priced gourmet market, the potential market for this type of system is 1imited. Therefore, the potential for use of waste heat in culturing these species is also limited. Since most of the proposed cultured species are marine animals, these aquaculture systems could use only waste heat from power plants located in coastal areas. Additionally, most of these species have a relatively low optimal growing temperature and could only use power plant reject heat during the winteri.

Analysis of an aquaculture system using mostly herblvorous species In pond culture has shown this to be an economically attractive system. Although yields are lower than those of intensive aquaculture systems, production costs are reduced by eliminating supplemental feeding, high technology equipment, and labor intensive management techniques. The potential market for these products is larger than that of high priced products, thus providing a larger potential use for power plant waste heat. The potential for waste heat utilization is further enhanced by the required heat addition year round for both the algal and animal growing ponds. Analysis has shown that the aquaculture system can be designed to meet almost $50 \%$ of the power plant sumer heat refection needs, while maintaining full production all year, or to meet the total heat rejection needs of the power plant and reduce production during the winter. It has also been shown that the economic cholce depends on 
site specific economic parameters and should be analyzed for each location.

In addition to utilizing a wasted energy source (1.e. power plant reject heat) to produce reasonably priced protein, the proposed system could provide tertlary sewage treatment for municipal sewage effluent.

Several possible problem areas have been identified. However, none of these appears to be without a technical solution.

Although each of the Individual components of the system has been proven technologically feasible, a pilot operation should be undertaken to demonstrate the technological feasibility of the integrated system. This phase should address species selection questions and would be useful in defining system synergistic effects. In addition to exploring technical questions, the demonstration facility would provide operational data that would be useful in determining the overall economic feasibility of the system.

The analysis in this report indicates that a waste heat aquaculture system, producing reasonably priced protein, appears to be technically feasible and economically attractive in the U.S. and a pilot scale experimental facility should be operated. 
REFERENCES

1. L. R. Gallese, "U.S. Firms are Hoping to Net Big Profits in Rapidly Expanding Fish-Farm Industry," Wall St. J., p. 46 (Jan. 6, 1976).

2. B. Conner, "Fish Farm Fiasco," Elements, p. 11 (March 1976).

3. "Product-Inventory-Sales Data," Commercial Fish Farmer and Aquaculture News 2(3), 33 (March 1976).

4. "Idaho's Water-Rich Magic Valley: Heart of the Food Trout Industry," Commercial Fish Farmer and Aquaculture News 2(4), 4 (May 1976).

5. C. V. W. Malinken, "Status Report Commerclal Salmon Culture in Puget Sound," Commercial Fish Farmer and Aquaculture News 2(1), 8 (September-October 1976).

6. H. J. Bowen, "Fresh Water Power Plant Aquaculture," In Proceedings of Power Plont Waste Ileat Utilization in Aquaculture - Workehop I, Trenton, N.J., Nov. 6-7, 1975.

7. P. J. Campbel1, "Commercial Oyster Aquaculture In a Heated Effluent," in Proceedings of Power Plant Waste Heat Utilization in Aquaculture Workshop I, Trenton, N.J., Nov. 6-7, 1976.

8. D. K. Cox and C. C. Coutant, "Growth-Temperature Response of Striped Bass Morone saxatilis," In Proceedings 2nd Thermal Ecology Symposium, Augusta, Ga., April 2-5, 1975.

9. C. C. Coutant and D. K. Cox, "Growth Rates of Subadult Largemouth Bass, $24-35.5^{\circ} \mathrm{C}$," in Proceedings and Thermal Ecology Symposizm, Augusta, Ga., Apri1 2-5, 1975.

10. J. C. Van 01st et al., "Use of Thermal Effluent in Culturing the American Lobster," in Proceedings of Power Plant Waste Heat Utilization in Aquaculture - Workshop I, Trenton, N.J., Nov. 6-7, 1976.

11. J. H. Ryther, "Mariculture: How Much Protein and For Whom?" Oceanus 18(2), 10-22 (1975).

12. J. E. Bardach, J. H. Rythler, and W. O. McLarney, Aquaculture, Wiley-Interscience, New York, 1972.

13. V. R. P. Sinha and M. V. Gupta, "On the Growth of Grass Carp, Ctenophamyodon IdelZa Val. in Composite Fish Culture at Kalyani, West Bongal (Ind1a)," Aquaculture 5, 283-290 (1.975).

14. Anon., "Sewage for T1lap1a," Fioh Farming Int. 2, 108-109 (1974).

15. D. Walrath and A. S. Nather, "Aquaculture - New Broom Cleans Up Wastewater," Water and Wastes Eng., pp. 38-41 (February 1976).

16. L. Boersma et al., Animal Waste Conversion Systems Based on Thermal Discharges, Speclal Report 416, Agricultural Experiment Station, Oregon State University (September 1974).

17. W. J. Oswald and C. G. Golueke, "Large-Scale Production of Algae," in Single Cell Protein, ed. by R. I. Mateles and S. R. Tannenbaum, M.I.T.Press, 1968. 
18. J. H. Douglas, "Oysters, Algae \& Sewage," Science News 106, 170-171 (Sept. 14, 1974).

19. E. Gasper et al., "Utilization of Waste Heat in a Biological System for the Conversion of Swine Manure to Single Cell Protein and Methane Gas," presented at American Soclety of Agriculture Engineers, Chicago, Ill., Dec. 15-18, 1975.

20. Anon., "Catfish Farming How to Make It a Profitable Operation," Commercial Fish Farmer and Aquaculture News 2(3) (March 1976).

21. Anon., "Farms as Suppliers of Quality Fish," Fish Farming Int. (2), 98-102 (1974).

22. John Ryther, Woods Hole Oceanographic Institute, personal communication to M. Olszewski, Oak Ridge National Laboratory, July 9, 1976. 


\section{THIS PAGE \\ WAS INTENTIONALLY \\ LEFT BLANK}


Appendix

TECHNICAL AND ECONOMIC ASSESSMENT OF CURRENT WASTE

HEAT AQUACULTURE APPLICATIONS

\section{RESEARCH PROGRAMS}

This Appendix will describe the major research efforts, now in progress, that seek to utilize power plant waste heat in aquaculture systems. These efforts are generally directed at basic biological questions (e.g., diet, optimal growth temperature, etc.) or system design problems associated with high density culture practices. Because some system design problems have not yet been solved, detalled economic feasibility studies have, generally, not been attempted. These major research efforts are mentioned below.

The Texas Agricultural Extension Service began its program in penaeid shrimp mariculture in $1969 .^{\mathrm{Al}}$. To explore the possibility of using power plant waste heat to extend the shrimp growing season, they expanded their program in 1972. In cooperation with the Central Power and Light Company, Ralston Purina and the University of Texas, a mariculture center was built at the Barney M. Davis Generating Station in Corpus Christi in 1972. Since the power station did not begin operation until 1975, their first pond system used unheated water from the Laguna Madre. This pond complex consists of a tri-level, three-pond pilot production module. The system is designed to recelve post-larval shrimp in the smallest unit, and as the animals grow, to move them through a pipe system to successively larger ponds. The complex consists of $0.06,0.11$, and 0.22 ha $(1 / 8,1 / 4$, and $1 / 2$ acre) ponds.

The second complex consists of eighteen 0.11 ha $(1 / 4$ acre) ponds that receive cool water from the power plant intake canal and warm water from the 1100-acre cooling lake. Their penaeid shrimp investigations are centered around the areas of stocking densities, feed, salinity and temperature questions and reproduction studies.

To date the major technological constraint affecting shrimp mariculture has been the inability of the culturist to induce shrimp to spawn 
in captivity. At the present time shrimp larvae are obtained by capturing gravid females from the Gulf of Mexico and transferring them to tanks. Their recent studies, however, have demonstrated that a large number of gravid females can be obtalned from an older, captive population that has been overwintered in heated water. Thus they have established the principle of using power plant waste heat beneficlally in shrimp martculture.

They have also demonstrated that the use of power plant waste heat can lengthen the shrimp growing season in Texas from the normal 6 months to 10 months. Since their shrimp mature to commercial size in 125 days, the longer growing season would allow shrimp farmers to raise an add1tional crop during the year.

From their studies they have concluded that the price of post-larval shrimp produced by hatcheries 18 , at present, restrictive to the commercialization of penaeld shrimp culture in the United States. The inflated price for seed shrimp is primarlly caused by the high cost of obtaining gravid female shrimp from the sea and the cost of operating existing hatcheries to produce the low volume of shrimp required.

Trenton State College, In cooperation with Public Service Electric and Gas Company (PSE\&G) and Rutgers University, is investigating the posstbillty of growing fresh water prawns (Macrobrachizm Rosenbergie) and rainbow trout (Salmo Gairdneri) to commerclal size using waste heat discharged from the PSE\&G Mercer Generating Station in Trenton, N.J. A2 The dual species system was adopted because winter water temperatures, even with the addition of power plant waste heat, were too low to allow prawn growth.

The Mercer aquaculture facility consists of two ponds, one $7.6 \times 27.4 \times 1.3 \mathrm{~m}(25 \times 90 \times 4 \mathrm{ft})$ the other $15.2 \times 15.2 \times 1.5 \mathrm{~m}$ $(50 \times 50 \times 5 \mathrm{ft}), a 2.4 \times 50.3 \times 0.9 \mathrm{~m}(8 \times 165 \times 3 \mathrm{ft})$ raceway and two laboratorles which also serve as nurserles for growing early and late prawn larvae to juvenile sizes. All ponds recelve water directly from the discharge canal of the generating station and empty back into 1 t. The power plant cooling system, itself, is a once-through system.

Post-larval freshwater prawn are obtained from Long Island Oyster Farms and are grown to juvenile size (about $2 \mathrm{~cm}$ in length) in nursery 
facilities at the Mercer Laboratories. During the first season (1974), the fuventles were stocked in an outdoor pond at a density of 10.8 animals $/ \mathrm{m}^{2}$ ( 1 animal $/ \mathrm{ft}^{2}$ bottom surface). Growth averaged $16 \mathrm{~mm}$ per month during the $31 / 2$-month experiment (June-October 1974). The survival rate for this experiment was $90 \%$.

During the second season (1975), Juveniles at $30 \mathrm{~mm}$ ( $1 \mathrm{in.}$ ) were stocked in three outdoor ponds at a density of $54 \mathrm{animals} / \mathrm{m}^{2}$ of bottom surface ( 5 animals/ $\mathrm{ft}^{2}$ bottom surface). However, sufficlent netting was draped in the ponds to reduce the animal to surface ratio to 1.5 . Growth averaged $13 \mathrm{~mm}(0.3 \mathrm{in.})$ and $3.4 \mathrm{~g}\left(7.5 \times 10^{-3} \mathrm{lb}\right)$ per month.

Trout fingerlings at $178 \mathrm{~mm}$ ( $7 \mathrm{in.}$ ) were stocked in an outdoor pond beginning in mid-November 1974, with final stocking occurring in December 1974. The initial weights of the fish varied between 65 and $93 \mathrm{~g}$ $(.14-.211 \mathrm{~b})$.

Most of the trout were harvested in late April 1974. These animals averaged $254 \mathrm{~mm}$ (10 in.) in length and $181 \mathrm{~g}(0.4 \mathrm{lbs})$ in weight. It was observed that no mortalities occurred after the fish recovered from the trauma of stocking. Also, no disease problems were observed during the 5-month growth period in the ponds. The major technical and economic problem with this system is the inability to close the prawn life cycle in confinement. The major cost item in this experimental system is feed cost. If the system were to expand to commercial scale, post-larval or juvenile stock would also present economic problems.

San Diego State University has been experimenting with temperature and diet in an effort to make lobster mariculture commercially attractive (Ref. 10 of text). They have laboratorles at Scripps Laboratory and at power plants at Carlsbad, California, and Redondo Beach, California. They have determined that the optimal growing temperature for the American Lobster (Homarus Americans) is $22^{\circ} \mathrm{C}\left(71.6^{\circ} \mathrm{F}\right)$. They have also had success In controlling mating and have hatched eggs from both American and European (Homams Gommams) lobster. Their present rearing method utilizes mass rearing for 8 months followed by individual rearing, until market size is attained, to reduce losses due to cannibalism. Their studies on heavy metal uptake Indicate that concentrations of heavy metal in the diet are more important than those in the water. They have raised 
three dozen lobsters to $0.45 \mathrm{~kg}$ ( 1 1b) market size in 3 years, one-third the time it takes in the ocean (Ref. 1 of text). However, they feel that the growing time must be shortened to between 18 months and 2 years to make commercial production practical. The estimated cost of producing these $454 \mathrm{~g}$ ( $1 \mathrm{lb}$ ) animals is $\$ 5.65$, half of which $1 \mathrm{~s}$ for heating the water. Use of power plant waste heat could, therefore, substantially reduce the figure. Another principal economic problem is the high cost of food. The customary lobster diet is artemia (brine shrimp) which costs about $\$ 2.20 / \mathrm{kg}$ ( $\$ 1$ per $1 \mathrm{~b})$. Studies are now belng performed to delermine if red crab meat, at $\$ 0.55 / \mathrm{kg}$ (25\& per 1b) is a feasible substitute.

Oregon State University (Ref. 16 of text) has been working to demonstrate the feasibility of using waste heat in the blological recovery of nutrients from a swine waste management system. The system essentially utilizes swine waste as the nutrient source for an algal and bacteria culture. The algal biomass is harvested by centrifuging and dried for use as animal feed. Simulated power plant waste heat is used in this system to enhance the blological recovery of nutrients by providing optimal growth temperatures for the culture.

Water from a syphon-activated flush tank is used to transport the manure from hog pens into a sump where the solids are separated from the liquids. The solids are then pumped into an anaerobic digester for liquefication and biogas production. The liquids are overflowed into a holding tank and pumped daily into $0.5 \mathrm{~m}^{3}$ (177 $\left.\mathrm{ft}^{3}\right)$, open-a1r growth basins for recovery of nutrients by algae and bacteria.

The test alga is the high temperature strain Chlorella vulgaris $211 / 8 \mathrm{~K}$.

They have found that high inorganic nitrogen (greater than $300 \mathrm{mg} / \mathrm{l}$ ) composition of the swine waste favored bacterial growth. Under these conditions biomass concentrations of $1.4 \mathrm{~g} / \mathrm{l}\left(0.0941 \mathrm{~b} / \mathrm{ft}^{3}\right)$ were achieved with a crude protein content of $74 \%$.

At low nilrugen and carbon concentrations, algal growth was predominant. Average algal biomass concentrations reached $0.7 \mathrm{~g} / \mathrm{l}$ $\left(0.047 \mathrm{lb} / \mathrm{ft}^{3}\right)$ with a crude protein content of $55 \%$. 
Current studies are directed at determining the optimal culture depth and retention time for maximum algal production.

Several other research programs are of interest, even though they do not presently use waste heat; among them are the Tennessee Valley Authority (TVA) project at Muscle Shoals, Alabama, and the efforts of Woods Hole Oceanographic Institute. The TVA effort is directed at developing a swine waste/algae/fish culture. Swine waste is added to unheated algal growth tanks where natural wild algal spectes are cultured. The alga is then transferred to fish tanks where White Amur, a Chinese grass carp, are grown. This fish is a gill feeder, having a large water throughput capability and is ideally suited to algae feeding.

Preliminary results indicate higher growth rates and lower mortality than expected. Feeding rates for the period of growth (early life) observed are also higher than expected.

These fish can reach $13.6-18.2 \mathrm{~kg}(30-40 \mathrm{lb})$ size, however, the experiment will be terminated before a $0.34 \mathrm{~kg}(3 / 4 \mathrm{lb})$ size is attained. This is because the experimental setup is unheated and will be interrupted In late fall.

The Woods Hole Oceanographic Institute profect Involves a marine application of the waste product to protein concept. They are operating an unheated pllot scale project at Woods Hole, Massachussetts, producing oysters and commercially valuable seaweeds. The system uses secondary sewage effluent as the nutrient source for an algal growth pond. The effluent from the algal pond flows through an aerated raceway containing oysters suspended in the water on trays. After the oysters filter the algae the water flows to the seaweed growth basins, where the seaweed culture extracts the remaining nutrients. The effluent from the seaweed culture is essentially free of nutrients and has been purffled to a state equivalent to standard tertiary sewage treatment. Therefore, the system functions as a tertiary treatment facility for municipal sewage and utilizes the nutrients to produce protein and seaweed. 
COMMERCIAL VENTURE

Maine Salmon Farms have been farming Coho salmon for a little over 4 years on the Sheepscot River (a salt water estuary) in Wiscasset, Maine. $^{\mathrm{A} 3}$ They have marketed $13,608 \mathrm{~kg}(30,000 \mathrm{lb})$ of yearling $0.22-0.34 \mathrm{~kg}$ $(1 / 2$ to $3 / 4 \mathrm{lb})$ fish in the last $11 / 2$ years and estimate that production will rise to $22,680 \mathrm{~kg}(50,000 \mathrm{lb})$ in 1976 and $27,200-34,000 \mathrm{~kg}$ $(60,000-75,000 \mathrm{lb})$ in 1977.

Their approach to salmon farming begins with the purchase of Coho salmon eggs from the Northwest Coast in the fall. The eggs are then hatched in fresh water in January. As the salmon fry grow, salt water is introduced into their growing environment. In the spring they are placed in nylon netpens in the estuary.

The growing pens are adfacent to the Central Malne Power Company's Mason Station, where the warm water discharge is used to increase the water temperature in the pen area during the winter months. The power plant discharges $3.15 \mathrm{~m}^{3} / \mathrm{sec}(50,000 \mathrm{gpm})$ of salt water that has been heated $11^{\circ} \mathrm{C}\left(20^{\circ} \mathrm{F}\right)$ above the ambient water temperature. This results in approximately a $2.8^{\circ} \mathrm{C}\left(5^{\circ} \mathrm{F}\right)$ rise in water temperature in the pen area. This increase in water temperature is used to stimulate fish growth during the eight colder months of the year. In the summer months, when heated water is not desirable, the power plant discharge is deflected from the pens by a boom.

The salmon attain market size in about 14 months. They harvest weekly, year round, and ship fresh salmon directly to restaurants on the New England Coast and New York City. At the present time they recelve an average of $\$ 4.96 / \mathrm{kg}(\$ 2.25 / 1 \mathrm{~b})$ and demand exceeds supply.

Disease 1s, at present, the major production problem. The total mortality from egg to market is about $40 \%$. Most of this occurs in the small fish during July and August when the water temperature rises above $15.5^{\circ} \mathrm{C}\left(60^{\circ} \mathrm{F}\right)$. They feel that this mortality rate is economically tolerable because very little money has been invested in the fish at this point.

Their projections show that production costs are in the neighborhood of $\$ 407 / \mathrm{kg}(\$ 1.85 / \mathrm{lb})$ at a production level of $22,680 \mathrm{~kg}(50,000 \mathrm{lb})$. 
The cost is substantially reduced at higher production levels and drops to $\$ 2.98 / \mathrm{kg}(\$ 1.35 / 1 \mathrm{~b})$ at a production level of $113,400 \mathrm{~kg}(250,000 \mathrm{lb})$. They feel that it is at the production level that salmon aquaculture will become profitable.

One of their major cost items is feed. The salmon are fed a mixture of wet and dry diet. The dry diet is constituted of herring meal, wheat middling, fish oil, and added vitamins. The wet diet is composed of ground and frozen by-products from the fishing industry such as shrimp and herring. They estimate that the feed cost to produce $0.45 \mathrm{~kg}$ ( $1 \mathrm{lb})$ of $\mathrm{fish}$ is approximately 35c. Therefore, at a profitable production level $(\sim 113,000 \mathrm{~kg}$ ), feed costs would represent about $25 \%$ of the production costs.

Long Island Oyster Farms began growing the American oyster (Crossostrea virginica) experimentally in the early 60's. By the late 60 's they constructed one of the world's largest hatcherles and began commercially producing millions of oyster seedlings (Ref. 7 of text).

The hatchery uses heated condenser effluent from the Long Island Lighting Company (LILCO) Northport plant, to enhance growth, in the production of their seedlings. The LILCO plant consists of three $389 \mathrm{MW}$ oil-fired plants. They discharge a total of $29.6 \mathrm{~m}^{3} / \mathrm{sec}(470,000 \mathrm{gpm})$ of seawater, which has been heated about $14^{\circ} \mathrm{C}\left(26^{\circ} \mathrm{F}\right)$ above ambient, into a 4-ha (10-acre) basin, about $1.8 \mathrm{~m}$ (6 ft) deep. Unheated seawater is mixed with the condenser effluent to prevent the lagoon temperature from exceeding $32^{\circ} \mathrm{C}\left(90^{\circ} \mathrm{F}\right)$.

Their culture technique consists of two stages. First, adult oysters are spawned and their offspring reared, under closely controlled conditions in the nursery, to transplanting size of a few millimeters in a period of about 6 weeks. These infant larvae are raised on a diet of algae grown with fertilizer, which represents about $20 \%$ of operating costs.

Next, the oysters are placed in the warm water of the lagoon in totally enclosed screens. The growing cycle in the lagoon may take from 6 weeks to 3 months, depending upon the time of the year. The oysters are then transferred from the lagoon to the natural environment.

At the time of transfer the oysters are at a size comparable to a natural 1-year old oyster. Oysters produced in this manner are, 
generally, better shaped, have better shell growth, and are fatter than natural oysters. This method of rearing also reduces the time required to reach marketable size to $21 / 2$ to $31 / 2$ years, from a normal time of 4 to 6 years, and increases the oyster survival rate.

To make this system of oyster rearing possible, the power plant has had to cease using chlorination to prevent condenser fouling. LILCO has converted to mechanical condenser cleaning methods that include the Amertap system, which employs abrasive sponge balls recirculated through the condenser tubes, and the Mann system, which utilizes brushes forced through the tubes.

At present, commerctal sales of approximately $\$ 5$ million are being achieved; and experiments are being performed with scallops, clams, shrimp and some $f$ in fish to determine if commercial production is feasible. International Shellfish Enterprises (ISE), in cooperation with Pacific Gas and Electric Company (PG\&E), has been experimenting with shellfish cultivation in the heated effluent from a PG\&E fossil plant at Moss Landing near Santa Cruz, California, since 1969. Commercial operation began in mid-1973. ${ }^{\mathrm{A}}$ Oysters are hatched and kept, for about 6 months, in a nursery maintained at 22 to $26^{\circ} \mathrm{C}\left(72\right.$ to $\left.79^{\circ} \mathrm{F}\right)$, before. being put 1nto a lagoon for 18 months to complete their growth. Eastern oysters were being produced at a rate of 1 million per year in 1974 . Future plans call for production to rise to 10 to 12 million oysters per year. ISE is also participating in a cooperative program with a Japanese group and expects to use their expertise for commercial production of abalone. 


\section{REFERENCES}

A1. F. S. Conte, "Penaeid Shrimp Culture and the Utilization of Waste Heat Effluent," in Proceedings of Power Plant Waste Heat Utilization in Aquaculture - Workshop I, Trenton, N.J., Nov. 6-7, 1976.

A2. A. F. Eble et a1., "The Use of Thermal Effluents of an Electric Generating Station in New Jersey in the Culture of the Tropical Prawn, Macrobrachizon Rosenbergii, and the Rainbow Trout, Salmo Gairdneri," In Proceedings of Power Plant Waste Heat Utilization in Aquaculture - Workshop I, Trenton, N.J., Nov. 6-7, 1976.

A3. F. C. Towle and R. C. Gower, "Commercial Salmon Culture on the Maine Coast," in Proceedings of Power Plant Waste Heat Utilization in Aquaculture - Workshop I, Trenton, N.J., Nov. 6-7, 1976.

A4. W. K. Furlong and L. D. King, "Beneficial Uses of Waste Heat-Status of Research and Development in the USA," presented at Joint US/USSR Meeting on Heat Rejection Systems, Washington, D.C., June 17-19, 1974. 
THIS PAGE

\section{WAS INTENTIONALLY LEFT BLANK}


ORNL/TM-5663

\section{Internal Distribution}

\author{
1. T. D. Anderson \\ 2. S. I. Auerbach \\ 3. S. E. Bea11 \\ 4. W. B. Cottrell \\ 5. C. C. Coutant \\ 6. D. K. Cox \\ 7. F. L. Culler \\ 8. G. G. Fee \\ 9. M. J. Goglia \\ 10. R. F. Hibbs \\ 11. H. W. Hoffman \\ 12. R. E. MacPherson \\ 13. W. J. McCarthy, Jr. \\ 14. J. W. Michel \\ 16-61. M. O1szewsk1 \\ 62. C. Oen
}

63. H. Postma

64. S. A. Reed

65. M. W. Rosenthal

66. M. R. Sheldon

67. M. J. Skinner

68. I. Spiewak

69. J. S. Suffern

70. J. J. Taylor

71. D. B. Trauger

72. G. D. Whitman

73. W. J. Wilcox

74-75. Central Research Library

76. Document Reference Section

77-79. Laboratory Records Department

80. Laboratory Records, RC

\section{External Distribution}

81-82. Director, Division of Nuclear Research and Application, ERDA, Washington

83. Director, ERDA, ORO

84. Research and Technical Support Division, ERDA, OR

85-111. Technical Information Center, OR

1i2. D. Linz, ERDA, OR

113. W. F. Savage, DNRA, ERDA, Washington

114-117. Ira Helms, DNRA, ERDA, Washington

118. L. F. Diaz, University of California, Berkeley, Berkeley, Calif.

119. P. B. Youngberg, National Marine Fisheries Service, Atlanta, Ga.

120. Maxine L. Savitz, Director, Division of Buildings \& Industry, ERDA, Washington

121. John A. Belding, Assistant Director, Division of Conservation Research and Technology, ERDA, Washington

122. Dr. Heyward D. Hamilton, Division of Blomedical and Environmental Research, ERDA, Washington

123. William R. Cherry, Chief, Agriculture and Process Heat Branch, ERDA Division of Solar Energy, Washington

124. Dr. Richard H. Bleiden, Biomass, Ocean \& Wind Systems, ERDA Division of Solar Energy, Washington

125. Dr. Edward Bryan, National Science Foundation, 1800 G St. N.W., Washington

126. Dr. Edward Gaines, Vermont Yankee Nuclear Power Corp., 77 Grove St., Rutland, Vermont

127. Jim Chasse, EPA, Corvallis, Oregon 